STUDIA PRAWNO-EKONOMICZNE, t. CV, 2017

PL ISSN 0081-6841; e-ISSN 2450-8179 s. 243-257

DOI: 10.26485/SPE/2017/105/14

\title{
Emilia KLEPCZAREK*
}

\section{CORPORATE GOVERNANCE THEORIES IN THE NEW INSTITUTIONAL ECONOMICS PERSPECTIVE. THE CLASSIFICATION OF THEORETICAL CONCEPTS}

\begin{abstract}
(Summary)
The inter-disciplinarity and multi-paradigmatism of corporate governance issues results in a lack of clear categorization of the theories. This paper attempts to systematize theories of corporate governance with special emphasis on the new institutional economics (NIE) framework and suggests new concepts for systematization. It allows us to understand better the limitations of each theory, and thus to choose the best one in particular circumstances, as well as provide them with the best available methodology. Bringing all the theories into the paradigm of NIE makes them closer to real market conditions and enables us to use methods attributed to neo-institutional research.
\end{abstract}

Keywords: neo-institutionalism; typology of theories; agency theory; stakeholders perspective; transaction costs

JEL Classification: D02, G34

\section{Introduction}

The research on corporate governance issues concerns not only economics but also management, accounting, finance, law, psychology, and sociology. It is difficult to point to one universal definition of corporate governance, as it is a complex, multiparadigmatic and highly interdisciplinary subject. Therefore it is not surprising that in the literature numerous theories of corporate governance are proposed. It seems to be associated with an attempt to emphasize different aspects occurring in the relationships inside and outside the analyzed corporations. These theories

* Assistant, University of Lodz, Department of Institutional Economics; e-mail: e.klepczarek@ uni.lodz.pl 
can be mutually contradictory, complementary or neutral ${ }^{1}$. They may emphasize different or similar problem areas and may be applicable to different or similar market conditions.

At the same time, in the literature we cannot find any universal unambiguous typology ${ }^{2}$ of corporate governance theories, which is further compounded by the simultaneous development of theories within mainstream economics, and then the turn of researchers to the institutional analysis. Hence, there arises a problem - is it possible and reasonable to transform the governance theories based on the neoclassical paradigm into the neo-institutional theories and whether to distinguish between "purely" institutional theories based on the analysis of transaction costs, and those that do not explicitly refer to the analysis of institutions and transactions.

This paper aims to systematize corporate governance theories and to discuss why it is important to look at them through the prism of new institutional economics (NIE). Particularly, it concentrates on bounded rationality ${ }^{3}$ and selfinterestedness leading to opportunistic behavior understood as "self-interest seeking with guile"4. Thus, if the universal neoclassical models are often replaced with models considering the above mentioned assumptions, why not think about these assumptions in terms of the common corporate governance theories as well? The conclusions of the analysis conducted in the paper confirm that NIE opens up new possibilities for interpretation of corporate governance theories and broadens the scope of their application.

In the typology finally proposed the theories are divided into comprehensive and restrictive and it is suggested that the restrictive theories can be applied within the comprehensive ones. All the existing concepts are also interpreted in terms of NIE. This kind of interpretation makes them closer to the real market conditions in which the analyzed entities operate. The important suggestion involved in the systematization described below is to classify the agency and the stakeholder theories as the general assumptions for a better understanding of market functioning that can be applied to every corporate governance theory included in the classification.

1 The agency and stewardship theories, or the shareholders and stakeholders perspectives, are often indicated as contradictory, the transaction costs theory and theory of contracts are found as complementary, and others as neutral as they concern different aspects of business environment.

2 The author uses terms 'typology' and 'classification' interchangeably. However, the typology may be defined as another term for a classification (for details see: K.D. Bailey, Typologies and taxonomies. An Introduction to Classification Techniques, Sage Publications, 1994).

H. Simon, Models of Man, John Wiley, New York 1957.

4 O.E. Williamson, Markets and Hierarchies, Analysis and Antitrust Implications: A Study in the Economics of Internal Organization, Free Press, New York 1975, p. 255. 


\section{Corporate governance, new institutional economics - definitions and assumptions}

There is no universal definition of corporate governance. The range of issues analyzed in this field of knowledge is very broad and is still evolving. Originally, corporate governance was identified only within the legal system, resulting from "specific rules - more or less precise statutory requirements governing shareholder meetings, the election of directors, notice requirements"s. Nowadays it is usually understood under Blair's definition and is about "a whole set of legal, cultural and institutional arrangements that determine what public corporations can do, who controls them, how this control is exercised and how the risks and return from the activities they undertake are allocated"6.

Further expanding the scope of the corporate governance research area to other stakeholder groups and other aspects of the corporate relationship has given rise to many theories of governance (principal-agent problem, stakeholders' perspective, stewardship theory, resource dependency theory, et al.). Each of these theories describes certain elements, highlights certain problems, provides compelling arguments in their explanation and facilitates an understanding of the processes taking place in the business reality. It should be noted, however, that none of these could be regarded as the universal theory, which would provide a holistic view of the organization from the point of view of the supervisory process.

At the same time, simultaneously with the expansion of corporate government theories, in economics and management science one may observe a turn towards interdisciplinary interpretation of economic phenomena, which is most stressed in the new institutional economics perspective. This term introduced to the literature by Williamson" emphasizes the difference from the so-called "old institutionalism", represented by Veblen and Commons ${ }^{8}$. It is a still developing

5 R.J. Gilson, Corporate Governance and Economic Efficiency: When Do Institutions Matters?, Washington University Law Review 1996/74, p. 327.

6 M.M. Blair, Ownership and Control: Rethinking Corporate Governance for the Twenty-First Century, Brookings Institution Press, Washington DC 1995, p. 19.

O.E. Williamson, Markets...

8 The main difference that distinguishes the "old" institutionalism from NIE is the attitude towards institutions: new institutional economics considers institutions as devices that individuals use in order to simplify the environment while in old-original institutional economics institutions are rather ways of thinking reflecting accepted norms of behaving (see: A. Ambrosino, M. Fontana, A.A. Gigante, Shifting Boundaries in Economics: The Institutional Cognitive Strand, Working Paper 44/15, The Department of Economics and Statistics Cognetti de Martiis, Universita Degli Studi di Torino, Torino 2015). 
theoretical viewpoint cultivated not only by economists but also by sociologists, psychologists, political scientists and lawyers.

The new institutional economics moves from focusing on the results of allocating resources to the coordination processes that lead to particular decisions about this allocation. Such an approach opens the way to more detailed research on institutions within and outside the corporation. And where the corporate institutions are concerned, there would always be corporate governance issues analyzed. This is, among other things, why corporate governance should be confronted with the main NIE assumptions. Taking the above into account, we may claim that new institutional economics pivots on three elements: institutions, governance structures and individuals whose interaction determines the development and performance of the economies ${ }^{9}$. It must be noted, however, that governance structure is found by Williamson as the 'institutional framework within which the integrity of a transaction is decided ${ }^{10}$ ' and such a definition equates 'governance structures' with 'institutions'.

\section{The typologies of corporate governance theories - examples from the literature}

As is noted by Mesjasz, despite the considerable attention devoted to theoretical problems of corporate governance, there dominate rather trivial interpretative discussions ${ }^{11}$. Peszko goes even further and states that "we must recognize an intimidating for the researcher, pluralism in theoretical approaches and a huge variety of postulated directions of improvement of the institutions of corporate governance"12. Nevertheless, there is a great deal of work done by Williamson showing that corporate governance can be seen through the lenses of the NIE theory ${ }^{13}$. At the same time, this turn towards the neo-institutional approach causes

9 A. Ambrosino et al., op. cit.

10 O.E. Williamson, Transaction-cost Economics: The Governance of Contractual Relations, Journal of Law and Economics 1979/22/2, p. 235.

11 C. Mesjasz, Teoretyczne podstawy władania korporacyjnego: Wprowadzenie (The theoretical basis of the corporate governance: Introduction), in: P. Urbanek (ed.), Nadzór korporacyjny a stabilność sektora finansowego (Corporate governance and the stability of the financial sector), Wydawnictwo Uniwersytetu Łódzkiego, Łódź 2012, pp. 179-194.

12 A. Peszko, Rada nadzorcza w procesie zarzadzania przedsiębiorstwem (The supervisory board in the enterprise management process), Difin, Warszawa 2006, p. 131.

13 O.E. Williamson, The New Institutional Economics: Taking Stock, Looking Ahead, Journal of Economic Literature 2000/XXXVIII, pp. 595-613. 
additional difficulties with the categorization of the existing theories. It also contributes to the lack of a coherent typology of the proposed concepts.

As we may observe (Table 1) there is no agreement on how to classify corporate governance theories. The reason for this is that different researchers use different dimensions or variables when grouping the theories. And it is here that an important question arises: What are the various classifications needed for? Bailey (1994) points out a few advantages of making classifications ${ }^{14}$. These are for example: description, reduction of complexity, identification of similarities and differences, presenting a list of dimensions or finding types as criteria for measurement. This last aspect seems to be of particular importance when one analyzes the theories in terms of the neoclassical or neo-institutional approach. There are methodological differences in, for example, cost calculation, within neoclassical (without transition casts) and neo-institutional models (including transaction costs).

Yet, as one may notice, the systematization of institutional and neoinstitutional approaches seems to be unclear. While Wolf ${ }^{15}$ proposes a group of neo-institutional theories, Hung ${ }^{16}$ proposes a group of institutional theories classifying the concepts differently than those of Wolf, Klettner ${ }^{17}$ finds institutional theory as an independent concept, and Charreaux ${ }^{18}$ and Urbanek ${ }^{19}$ do not mention such perspectives. Urbanek however points out the existence of transaction cost theory derived directly from the neo-institutional paradigm.

${ }_{14}$ K.D. Bailey, op. cit., p. 12.

15 J.B. Wolf, The effects of agency problems on the financial behavior, performance and efficiency of German industrial stock corporations, Peter Lang Europaischer Verlag der Wissenschaften, Frankfurt am Main 1999.

16 H. Hung, A typology of the theories of the roles of the governing boards, Scholary research and theory papers 1998/6/2, pp. 101-111.

17 A. Klettner, Corporate Governance regulation. The changing roles and responsibilities of boards of directors, Rutledge, New York 2017.

18 G. Charreaux, Corporate Governance Theories: From Micro Theories to National Systems Theories, Working paper no 1041202, Centre de Recherche en Finance, Architecture et Gouvernance des Organisations, Université de Bourgogne, Dijon 2004.

19 P. Urbanek, Teoretyczne aspekty tadu korporacyjnego (The theoretical aspects of corporate governance), in: A. Adamska, C. Mesjasz, P. Urbanek (eds.), Teorie tadu korporacyjnego. Władanie i kontrola w złożonym świecie (Theories of corporate governance. Governance and control in a complex reality), Wydawnictwo Uniwersytetu Łódzkiego, Łódź 2016. 
TABELA 1: The examples of the typologies of corporate governance theories

\begin{tabular}{|c|c|c|c|c|}
\hline Wolf & Hung & Klettner & Charreaux & Urbanek \\
\hline $\begin{array}{l}\text { 1. Neo- } \\
\text { institutional } \\
\text { theories } \\
\text { a) based on the } \\
\text { motivational } \\
\text { function } \\
\text { - agency theory } \\
\text { - asymmetry of } \\
\text { information } \\
\text { - property rights } \\
\text { theory } \\
\text { b) transaction } \\
\text { costs theory } \\
\\
\text { 2. The other } \\
\text { theories } \\
\text { (of the } \\
\text { neoclassical } \\
\text { economics) }\end{array}$ & $\begin{array}{l}\text { 1. Contingency } \\
\text { perspective } \\
\text { a) external } \\
\text { environment } \\
\text { - resource } \\
\text { dependency } \\
\text { theory } \\
\text { - stakeholder } \\
\text { theory } \\
\text { b) internal } \\
\text { environment } \\
\text { - agency theory } \\
\text { - stewardship } \\
\text { theory } \\
\\
\text { 2. Institutional } \\
\text { perspective } \\
\text { a) institutionalized } \\
\text { through } \\
\text { external } \\
\text { pressure } \\
\text { - institutional } \\
\text { theory } \\
\text { b) institutionalized } \\
\text { through } \\
\text { internal } \\
\text { pressure } \\
\text { - managerial } \\
\text { hegemony }\end{array}$ & $\begin{array}{l}\text { 1. Management } \\
\text { theories on the } \\
\text { board } \\
\text { a) relating to the } \\
\text { purpose of the } \\
\text { company } \\
\text { - shareholder } \\
\text { primacy } \\
\text { - stakeholder } \\
\text { responsibility } \\
\text { b) relating to the } \\
\text { role of the board } \\
\text { - agency theory } \\
\text { - stakeholder } \\
\text { theory } \\
\text { - stewardship } \\
\text { theory } \\
\text { - resource- } \\
\text { dependency } \\
\text { theory } \\
\text { - institutional } \\
\text { theory } \\
\text { c) relating to the } \\
\text { board behavior } \\
\text { - behavior-based } \\
\text { theories } \\
\\
\text { 2. Regulatory } \\
\text { theories on the } \\
\text { use of soft law } \\
\text { a) theories } \\
\text { regarding } \\
\text { non-traditional } \\
\text { regulation } \\
\text { ('new } \\
\text { governance') } \\
\text { b) theories } \\
\text { regarding } \\
\text { meta- } \\
\text { regulation } \\
\text { c) theories } \\
\text { regarding } \\
\text { responsive } \\
\text { regulation } \\
\text { aldion }\end{array}$ & $\begin{array}{l}\text { 1. Micro theories } \\
\text { a) disciplinary } \\
\text { - shareholder } \\
\text { theory } \\
\text { - stakeholder } \\
\text { theory } \\
\text { b) knowledge- } \\
\text { based } \\
\text { - behavioral theory } \\
\text { - evolutionary } \\
\text { theory } \\
\text { - resources and } \\
\text { competence } \\
\text { theory } \\
\text { c) Synthetic } \\
\text { theories } \\
\\
\text { 2. Macro theories } \\
\text { of the National } \\
\text { Systems of } \\
\text { governance } \\
\text { a) Law and } \\
\text { finance theory } \\
\text { b) Evolutionary } \\
\text { law and finance } \\
\text { theory } \\
\text { c) Politico- } \\
\text { financial } \\
\text { theory } \\
\text { d) Extension and } \\
\text { generalization of } \\
\text { the political } \\
\text { theory } \\
\text { e) Endowment } \\
\text { theory } \\
\text { f) Socio-cultural } \\
\text { theories } \\
\text { g) Varieties of } \\
\text { capitalism } \\
\text { theory } \\
\text { h) Regulation } \\
\text { theory and the } \\
\text { SSIP theory }\end{array}$ & $\begin{array}{l}\text { 1. Orthodox } \\
\text { theories } \\
\text { a) agency theory } \\
\text { b) stewardship } \\
\text { theory } \\
\text { c) stakeholders } \\
\text { theory } \\
\text { d) resource } \\
\text { dependency } \\
\text { theory } \\
\text { e) managerial } \\
\text { hegemony } \\
\text { theory } \\
\text { f) transaction } \\
\text { costs theory } \\
\\
\text { 2. Unorthodox } \\
\text { theories } \\
\text { a) social agency } \\
\text { theory } \\
\text { b) political } \\
\text { theory } \\
\text { c) cultural } \\
\text { dependency } \\
\text { theories } \\
\text { d) ethical } \\
\text { theories } \\
\text { e) legitimization } \\
\text { theory }\end{array}$ \\
\hline
\end{tabular}

S o u r c e: own elaboration. 
Apart from the lack of a clear classification of corporate governance theories postulated in the literature, it can be observed that the agency theory, considered so far to be the bedrock of corporate governance concepts ${ }^{20}$ is being displaced by the stakeholders theory that better fits the new institutional economics trend.

The criticism of the assumptions of agency theory which we can find in the literature ${ }^{21}$ does not weaken the key assumptions of this concept indicating the existence of conflicts between different interest groups (managers, shareholders, creditors, etc.). Therefore, as a valuable research approach, one could consider the proposal of Letza and $\operatorname{Sun}^{22}$ who treat the two dominant perspectives - the agency theory (shareholders' company) and the stakeholder theory (stakeholders' company) as competing paradigms of corporate governance. As noticed by Sonmez and Yildirim corporate governance issues address two main problems: "the value maximisation of shareholders and the role of stakeholders in the management system of corporations" ${ }^{\prime 2}$. Thus, it may be claimed that agency and stakeholder theory should not always be treated as competing; they could be found as partial paradigms, or a kind of general perspectives always appearing in the company of each other. When the modern corporation is considered there shall always appear some kind of agency conflict caused by pressure from different groups of stakeholders.

\section{Corporate governance theories in the NIE perspective, the concept systematization}

Taking into consideration the arguments presented in the previous Section, in the typology proposed in this paper the agency and stakeholders perspectives will not be treated as the other corporate governance theories. Rather, they will be found as the "starting points" for the further analysis. Nowadays, when separation of

20 K.M. Eisenhardt, Agency Theory: An Assessment and Review, Academy of Management Review 1989/14, pp. 57-74.

21 More about the criticism of the agency theory see: V. Brudney, Corporate governance, agency costs, and the rhetoric of contract, Columbia Law Review 1985/85 (7), pp. 1403-1444; M.J. Roe, A political theory of American corporate finance, Columbia Law Review 1991/91 (1), pp. 10-67.

22 S. Letza, X. Sun, Corporate Governance: Paradigms, dilemmas and beyond, The Poznan University of Economics Review 2002/2/1, pp. 43-65.

23 M. Sonmez, S. Yildirim, A Theoretical Aspect on Corporate Governance and Its Fundamental Problems: Is It a Cure or Another Problem in the Financial Markets?, Journal of Business Law and Ethics 2015/3/1 \& 2, p. 20. 
ownership from management is a common occurrence and relationships within the business environment are increasingly complex and complicated, it remains inevitable, above all, to delegate responsibilities and managerial activities (described by the agency theory) and the need to balance the great number of goals of many interest groups (described by the stakeholders theory). The other theories will be divided into two main categories: comprehensive and restrictive. The comprehensive theories consider market, social, behavioral, ethical or cultural relations in a wide sense, while the restrictive are focused on particular groups of problems or relations (see: Figure 1).

FIGURE 1: Corporate governance theories - the proposed typology
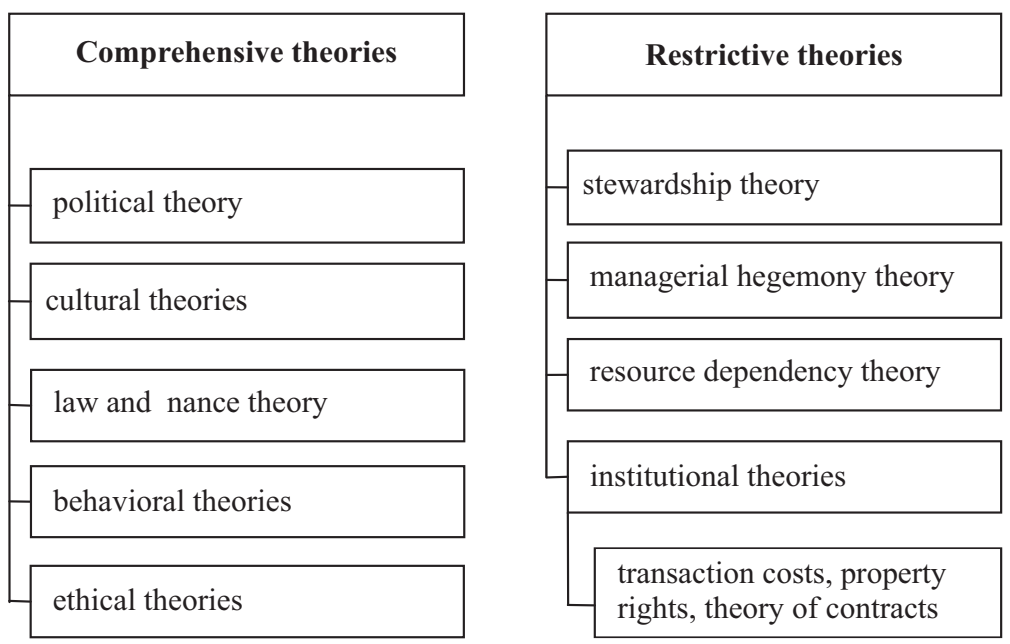

S o u r c e: own elaboration.

The agency theory highlights a potential conflict between principal and agent. However, Donaldson's research based on psychological and situational factors showed that this relationship should not always be regarded as conflictual ${ }^{24}$. The stewardship theory formulated on the basis of these observations does not set aside the NIE assumptions and does not preclude the manifestation of opportunistic behaviour other than that of managers, stakeholders. Other shareholders, employees or customers, who recognize the incompleteness of contracts or asymmetry of information, may use it to increase their own profits to the detriment of others.

${ }^{24}$ L. Donaldson, The ethereal hand: Organizational Economics and Management Theory, Academy of Management Review 1990/15/3, pp. 369-381. 
The professionalism and commitment of managers is strongly emphasized also by the managerial hegemony theory, according to which actual power and decision making processes in the company rest in the hands of managers ${ }^{25}$. If one considers this theory in the perspective of NIE, it could be recognized that the concept perceives the hegemony of management as a key coordinating rule and presents the specific manifestations of the adaptive efficiency ${ }^{26}$. It could be postulated that the dominant role of the managers and the marginal role of the board are in fact the result of adaptation of these bodies to the expectations or to the "silent consent" of other stakeholders and the conditions created by the institutional environment.

The importance of human resources, also including those other than the management bodies, is not marginalized by the resource dependence theory, according to which, the crucial assets that build corporate power should be valuable, unique and impossible to substitute ${ }^{27}$. It should be noted that the quality of the company's unique resources (specific competence, experience and personality traits) determines the efficiency of coordination processes and the firm's relationships with the business environment. And these two variables are fundamental elements of the neo-institutional analysis.

Other theories - the transaction costs, the property rights and the theory of contracts - are classified as institutional theories ${ }^{28}$. The term "institutional" refers here to institutions considered as neo-institutionalists which define them ${ }^{29}$. This means that "institutional" are also "neo-institutional". The author claims that all the corporate governance theories comply with the NIE paradigm and

25 M.L. Mace, Directors: Myth and Reality, Harvard University Press, Boston 1971.

26 As pointed in Section 2, NIE finds the adaptive efficiency as an important criterion for the efficiency of the economic system.

27 J.B. Barney, Firm Resources and Sustained Competitive Advantage, Journal of Management 1991/17, pp. 99-120.

28 There are some researchers finding the institutional theory as a separate corporate governance theory that focuses on analyzing the organizations' response to the institutional pressure and the internal forces clashing inside the organization (see: P. Selznick, TVA and the Grass Roots, University of California Press, Berkeley, CA 1957). Such an approach the author considers as adopting the stakeholders perspective as the dominant view in the corporate governance theories, and not as a separate theory.

29 Old-institutionalists find institutions more than mere tools (F.A. Hayek, The Sensory Order. An inquiry into the foundations of theoretical psychology, Routledge and Kegan Paul, London 1952), rather as "shared conventions, rules, routines and norms" (G.M. Hodgson, Institutional Economics into the Twenty-First Century, Studi e Note di Economia 2009/XIV/1, p. 3). NIE considers institutions as devices that individuals use in order to simplify the environment (A. Ambrosino et al., Shifting...). 
to emphasize that some of them base their main assumptions on the concept of transaction costs, they too are included in the institutional group.

As is noted by Coase $^{30}$, transaction costs dictate the decisions related to the contracting conditions of the projects within the organization. His concepts were developed by Alchian and Demsetz ${ }^{31}$ and Williamson ${ }^{32}$ who formulated the theory of transaction costs. This idea finds the costs of coordination and motivation as the main subject of analysis, and it states that transactions are conducted when such costs are their lowest. Allen points out that transaction costs result from the transfer of property rights ${ }^{33}$. The allocation of property rights, as well as their motivational role, are the main subjects of the analysis of the property rights theory described by Alchian and Demsetz ${ }^{34}$. The existence of transaction costs implies the necessity to conclude the so-called incomplete contracts ${ }^{35}$. This concept can be considered a kind of a synthesis of the approaches concerning the property rights (these are property rights that determine the privileged position of the contract parties) and transaction costs (contract terms are intended to minimize the costs of coordination and motivation) and such a view justifies including it into the institutional group.

The presented overview of the concepts does not include the whole catalog of theories explaining the mechanisms of corporate governance. In addition to the above mentioned, researchers indicate among others, political, cultural, law and finance, behavioral and ethical theories. It is worth noting that these theories consider corporate governance in a more holistic way, they do not focus on a particular area of intra-relationships. Therefore they are defined as comprehensive by the author. The list of comprehensive theories is not exhaustive, and any theory that fulfills the condition of being related to a state of social, economic, political, cultural, legal, behavioral or moral circumstances may be added to it. As with Charreaux's macro- and micro-theories division, it is assumed that within the comprehensive theories at the level of individual corporations there may be applied restrictive ones (stewardship, managerial hegemony, resource

30 R. Coase, The Nature of the Firm, Economica 1937/4, pp. 386-405.

31 A.A. Alchian, H. Demsetz, The property rights paradigm, Journal of Economic History 1973/33, pp. $16-27$.

32 O.E. Williamson, The Economic Institutions of Capitalism: Firms, Markets, Relational Contracting, Free Press, New York 1985.

33 D.W. Allen, Transaction Costs, in: B. Bouckaert, G. de Geest (eds.), Encyclopedia of Law and Economics, Edward Elgar, Cheltenham 2000, pp. 312.

34 A.A. Alchian, H. Demsetz, op. cit.

35 O. Hart, J. Moore, Incomplete Contracts and Ownership: Some New Thoughts, The American Economic Review 2007/97/2, pp. 182-186. 
dependency or institutional theories). The latter are called "restrictive" as they are limited to a narrow area of analyzing issues, usually without regard to the broader aspect of the external conditions.

All of the comprehensive concepts can also be considered in terms of the new institutional economics. They all relate to culture and norms that are found by Williamson as 'informal institutions' ${ }^{36}$. Understanding institutions in such a wide sense - as rules of the game limiting the uncertainty of decisions ${ }^{37}$ or shaping social interactions ${ }^{38}$ allows us to identify institutions with the principles recognized in law, culture, customs, tradition, common practices and conventions, which govern the corporate governance bodies. This theoretical construct opens the way to regard these theories as pointing out the main rules or norms in particular market circumstances. There may also be another interpretation - that institutions defined strictly according to North as rules (associated mainly by legal rules) - influence all the other areas - i.e. political, socio-cultural, financial, etc. It means that institutions are crucial in shaping law and finance, politics, sociocultural relations, legitimization issues and ethics (Table 2).

TABLE 2: The typology of corporate governance theories in the NIE perspective

\begin{tabular}{|l|l|}
\hline \multicolumn{1}{|c|}{ Theories } & \multicolumn{1}{c|}{ Interpretation in view of NIE } \\
\hline Stewardship theory & $\begin{array}{l}\text { RESTRICTIVE THEORIES } \\
\text { Emphasizing the opportunistic attitudes of other (not managers) } \\
\text { stakeholders who use the incomplete contracts and information } \\
\text { asymmetry. }\end{array}$ \\
\hline Ranagerial hegemony theory & $\begin{array}{l}\text { Recognizing the dominant role of the managers and the marginal } \\
\text { role of board as the result of adaptation of these institutions to } \\
\text { the expectations or to the "silent consent" of other stakeholders } \\
\text { and the conditions created by the institutional environment. }\end{array}$ \\
\hline Resource dependency theory & $\begin{array}{l}\text { Emphasizing the importance of the quality of the unique } \\
\text { resources of the company (including primarily the governance } \\
\text { institutions) determining the efficiency of coordination processes } \\
\text { and the firm's relationships with the business environment. }\end{array}$ \\
\hline
\end{tabular}

36 O.E. Williamson, The New Institutional...

37 D.C. North, Institutions, Institutional Change and Economic Performance, Cambridge University Press, Cambridge 1990.

38 G.M. Hodgson, The Evolution of Institutional Economics. Agency, Structure and Darwinism in America Institutionalism, Routledge, London-New York 2004. 


\begin{tabular}{|l|l|l|}
\hline \multicolumn{2}{|c|}{ Theories } & \multicolumn{1}{c|}{ Interpretation in view of NIE } \\
\hline \multicolumn{3}{|c|}{ RESTRICTIVE THEORIES } \\
\hline \multirow{2}{*}{$\begin{array}{l}\text { Institutional } \\
\text { theories }\end{array}$} & $\begin{array}{l}\text { Transaction } \\
\text { costs }\end{array}$ & $\begin{array}{l}\text { Transaction costs as a measure of the efficiency of coordination } \\
\text { processes. }\end{array}$ \\
\cline { 2 - 3 } & $\begin{array}{l}\text { Theory } \\
\text { of contracts }\end{array}$ & $\begin{array}{l}\text { Searching for the most favorable allocation of property rights } \\
\text { from the point of view of minimizing the transaction costs. }\end{array}$ \\
\cline { 2 - 3 } & $\begin{array}{l}\text { Considering contracts as a means of limiting the information } \\
\text { asymetry and the opportunism of the institution members (thus } \\
\text { minimizing the transaction costs). }\end{array}$ \\
\hline \multicolumn{2}{|c|}{ COMPREHENSIVE THEORIES } \\
\hline $\begin{array}{l}\text { Political theory, cultural } \\
\text { theory, law and finance theory, } \\
\text { behavioral theories, ethical } \\
\text { theories, et al. }\end{array}$ & $\begin{array}{l}\text { Defining institutions as the principles recognized in law, culture, } \\
\text { customs, tradition, common practices and conventions, which } \\
\text { govern the corporate governance bodies. Or finding institutions } \\
\text { as crucial in shaping law and finance, politics, socio-cultural } \\
\text { relations, legitimization issues and ethics. }\end{array}$ \\
\hline
\end{tabular}

S o u r c e: own elaboration.

Table 2 presents a proposition of typology of corporate governance theories divided into comprehensive and restricted ones. As described above, all the restricted theories can be considered consistent with the NIE assumptions if there are emphasized the aspects mentioned in the table. The comprehensive theories refer to a lesser extent directly to the concept of transaction costs essential in neo-institutional analysis. Nevertheless they clearly accent the crucial role of the institutional environment, as a key determinant of the efficiency of coordination processes. Besides, it can be assumed that all governance modes have evolved in order to minimize transaction costs ${ }^{39}$ so they all somehow consider these issues, which is so important for NIE analysis.

\section{Conclusions}

The arising of the further corporate governance theories and the turn of researchers to neo-institutional approaches encourages to systematize the existing concepts and confront their assumptions with the new institutional economics paradigm. It remains an open question, whether one should try to reinterpret the classical theories in the light of neo-institutional assumptions. However, if we assume

39 P. Ollila, Principles of Institutional Economics: With Applications to Cooperative Enterprises, Working Paper No. 56, Department of Economics, Helsinki University 2009. 
after Rudolf, that the NIE approach is not competitive with classical analysis, but is a kind of perspective enriching the mainstream view, such a reinterpretation appears to be advocated ${ }^{40}$. After all we must remember that new institutional economics has its roots in neoclassical economics ${ }^{41}$.

The systematization suggested is an option, which could serve as a framework in order to bring together all the current approaches presented in the literature. These include in particular: finding the agency and stakeholder perspectives as background fundamental concepts for all other theories and interpreting the theories in view of NIE. All the author's suggestions are open research problems and may be found questionable. Nevertheless, the interpretation of the described doctrines in view of the new institutional economics may be considered useful as we observe the consistent development of this trend, whose basic units of analysis - institution and transaction - are directly related to the issues analyzed within the corporate governance research.

Eventually, there always comes the "so what?" question. Why is it important to systematize corporate governance theories and to look at them through the prism of new institutional economics? As is argued by Lynall et al., it is a task for academics to realize a vast range of theories that may be applied within research and to better understand the limits of each theory as well as the conditions determining whether it will apply ${ }^{42}$. Such an analysis should be followed with providing the best methodology that fits the chosen theory and denying some neoclassical assumptions makes it possible for researchers to benefit from the vast range of methods developed within NIE analyses.

\section{References}

Alchian Armen A., Demsetz Harold, The property rights paradigm, Journal of Economic History $1973 / 33$, pp. 16-27.

Allen Douglas W., Transaction Costs, in: Bouckaert Boudewijn, de Geest Gerrit (eds.), Encyclopedia of Law and Economics, Edward Elgar, Cheltenham 2000, pp. 893-926.

Ambrosino Angela, Fontana Magda, Gigante Anna A., Shifting Boundaries in Economics: The Institutional Cognitive Strand, Working Paper 44/15, The Department of Economics and Statistics Cognetti de Martiis, Universita Degli Studi di Torino, Torino 2015.

40 S. Rudolf, The Impact of Economic Crisis on Institutional Changes, in: J. Sepp, F. Dean (eds.), The Economy and Economics after Crisis, BWV Berliner Wissenschafts-Verlag, Berlin 2012, pp. 81-92.

${ }_{41}$ P. Ollila, op. cit.

${ }^{42}$ M.D. Lynall, B.R. Golden, A.J. Hillman, Board composition from adolescence to maturity: a multitheoretic view, Academy of Management Review 2003/28/3, pp. 416-431. 
Bailey Kenneth D., Typologies and taxonomies. An Introduction to Classification Techniques, Sage Publications, 1994.

Barney Jay B., Firm Resources and Sustained Competitive Advantage, Journal of Management 1991/17, pp. 99-120.

Blair Margaret M., Ownership and Control: Rethinking Corporate Governance for the Twenty-First Century, Brookings Institution Press, Washington DC 1995.

Brudney Victor, Corporate governance, agency costs, and the rhetoric of contract, Columbia Law Review 1985/85 (7), pp. 1403-1444.

Charreaux Gerard, Corporate Governance Theories: From Micro Theories to National Systems Theories, Working paper no 1041202, Centre de Rechercheen Finance, Architecture et Gouvernance des Organisations, Université de Bourgogne, Dijon 2004.

Coase Ronald, The Nature of the Firm, Economica 1937/4, pp. 386-405.

Donaldson Lex, The ethereal hand: Organizational Economics and Management Theory, Academy of Management Review 1990/15/3, pp. 369-381.

Eisenhardt Kathleen M., Agency Theory: An Assessment and Review, Academy of Management Review 1989/14, pp. 57-74.

Gilson Ronald J., Corporate Governance and Economic Efficiency: When Do Institutions Matters?, Washington University Law Review 1996/74, pp. 327-345.

Hart Oliver, Moore John, Incomplete Contracts and Ownership: Some New Thoughts, The American Economic Review 2007/97/2, pp. 182-186.

Hayek Friedrich A., The Sensory Order. An inquiry into the foundations of theoretical psychology, Routledge and Kegan Paul, London 1952.

Hodgson Geoffrey M., The Evolution of Institutional Economics. Agency, Structure and Darwinism in America Institutionalism, Routledge, London-New York 2004.

Hodgson Geoffrey M., Institutional Economics into the Twenty-First Century, Studi e Note di Economia 2009/XIV/1, pp. 3-26.

Hung Humpry, A typology of the theories of the roles of the governing boards, Scholary research and theory papers 1998/6/2, pp. 101-111.

Klettner Alice, Corporate Governance regulation. The changing roles and responsibilities of boards of directors, Rutledge, New York 2017.

Letza, Steve, Sun Xiuping, Corporate Governance: Paradigms, dilemmas and beyond, The Poznan University of Economics Review 2002/2/1, pp. 43-65.

Lynall Matthew D., Golden Brian R., Hillman Amy J., Board composition from adolescence to maturity: a multitheoretic view, Academy of Management Review 2003/28/3, pp. 416-431.

Mace Myles L., Directors: Myth and Reality, Harvard University Press, Boston 1971.

Mesjasz Czeslaw, Teoretyczne podstawy wtadania korporacyjnego: Wprowadzenie, in: P. Urbanek (ed.), Nadzór korporacyjny a stabilność sektora finansowego, Wydawnictwo Uniwersytetu Łódzkiego, Łódź 2012, pp. 179-194.

North Douglass C., Institutions, Institutional Change and Economic Performance, Cambridge University Press, Cambridge 1990.

Ollila Petri, Principles of Institutional Economics: With Applications to Cooperative Enterprises, Working Paper No. 56, Department of Economics, Helsinki University 2009.

Peszko Adam, Rada nadzorcza $w$ procesie zarzadzania przedsiębiorstwem, Difin, Warszawa 2006.

Roe Mark J., A political theory of American corporate finance, Columbia Law Review 1991/91 (1), pp. 10-67. 
Rudolf Stanisław, The Impact of Economic Crisis on Institutional Changes, in: Sepp Juriand, Dean Frear (eds.), The Economy and Economics after Crisis, BWV Berliner WissenschaftsVerlag, Berlin, 2012, pp. 81-92.

Selznick Philip, TVA and the Grass Roots, University of California Press, Berkeley, CA 1957.

Simon Herbert, Models of Man, John Wiley, New York 1957.

Sonmez Melih, Yildirim Suat, A Theoretical Aspect on Corporate Governance and Its Fundamental Problems: Is It a Cure or Another Problem in the Financial Markets?, Journal of Business Law and Ethics 2015/3/1 \& 2, pp. 20-35.

Urbanek Piotr, Teoretyczne aspekty ładu korporacyjnego, in: Agata Adamska, Czesław Mesjasz, Piotr Urbanek, Teorie ładu korporacyjnego. Władanie i kontrola w złożonym świecie, Wydawnictwo Uniwersytetu Łódzkiego, Łódź 2016.

Williamson Oliver E., Markets and Hierarchies, Analysis and Antitrust Implications: A Study in the Economics of Internal Organization, Free Press, New York 1975.

Williamson Oliver E., The Economic Institutions of Capitalism: Firms, Markets, Relational Contracting, Free Press, New York 1985.

Williamson Oliver E., The New Institutional Economics: Taking Stock, Looking Ahead, Journal of Economic Literature 2000/XXXVIII, pp. 595-613.

Williamson Oliver E., Transaction-cost Economics: The Governance of Contractual Relations, Journal of Law and Economics 1979/22/2, pp. 233-261.

Wolf Benedict J., The effects of agency problems on the financial behavior, performance and efficiency of German industrial stock corporations, Peter Lang Europaischer Verlag der Wissenschaften, Frankfurt am Main 1999.

\title{
Emilia KLEPCZAREK
}

\section{TEORIE NADZORU KORPORACYJNEGO W ŚWIETLE ZALOŻEŃ NOWEJ EKONOMII INSTYTUCJONALNEJ. PRÓBA USYSTEMATYZOWANIA KONCEPCJI}

\author{
(Streszczenie)
}

Interdyscyplinarność i wieloparadygmatyzm zagadnień związanych z nadzorem korporacyjnym utrudnia wskazanie jednolitej klasyfikacji teorii corporate governance. W artykule podjęto próbę usystematyzowania teorii nadzoru oraz skonfrontowania ich założeń z paradygmatem nowej ekonomii instytucjonalnej. Przeprowadzony przez autorkę przegląd podejść teoretycznych podkreśla ograniczenia każdej z zaprezentowanych koncepcji, pozwalając tym samym wybrać optymalną w określonych warunkach teorię oraz metodologię badań. Analizowane teorie zinterpretowane zostały również w świetle założeń NEI, co, w opinii autorki, zbliża je do rzeczywistych warunków, w jakich funkcjonują współczesne podmioty gospodarcze, oraz umożliwia wykorzystanie instrumentarium metodologicznego używanego $\mathrm{w}$ analizie neoinstytucjonalnej.

Słowa kluczowe: neoinstytucjonalizm; typologia teorii; teoria agencji; perspektywa interesariuszy; koszty transakcyjne 